Brit. F. industr. Med., 1968, 25, 176.

\title{
Byssinosis, Chronic Bronchitis, and Ventilatory Capacities in Workers Exposed to Soft Hemp Dust
}

\author{
F. VALIĆ, E. ŽUŠKIN, JOAN WALFORD, W. KERŠIĆ, and R. PAUKOVIĆ \\ From the 'Andrija Stampar' School of Public Health, Zagreb, the London School of Hygiene and Tropical Medicine, \\ and the Institute for Medical Research and Industrial Hygiene, Zagreb
}

A study was made of 93 women and 13 men employed in the spinning department of a factory in Yugoslavia processing soft hemp (Cannabis sativa). There were seven occupational groups, with average concentrations of total airborne hemp dust ranging from $2.9 \mathrm{mg} . / \mathrm{m} .{ }^{3}$ to more than $19.5 \mathrm{mg}$. $/ \mathrm{m} .{ }^{3}$. Thirtyeight women and II men, employed in other departments of the factory with average total dust concentrations below $\mathrm{r} \cdot 0 \mathrm{mg} . / \mathrm{m} .^{3}$, were studied as controls.

In the spinning department $40.6 \%$ of the workers had byssinosis and $15.1 \%$ had chronic bronchitis (defined as persistent cough and phlegm on most days for as much as three months each year during the last two years). None of the controls suffered from either disease.

After adjustment for age, sitting height, and sex, the F.E.V. $\cdot_{0.75}$ and F.V.C. measured at the beginning of the shift were used to assess the long-term effects of hemp dust on the ventilatory function of the lung. The age-adjusted ratio F.E.V.0.75 F.V.C. was also used. A comparison between the control group and the seven exposed groups showed no meaningful association between ventilatory function and present levels of dust exposure, but byssinotics with chronic bronchitis had a mean age-adjusted F.E.V $\cdot_{0.75} /$ F.V.C. ratio significantly lower than that of workers with neither disease $(P<0.05)$.

Acute effects of hemp dust, measured by the change in F.E.V.0.75 and F.V.C. during the shift, were considerable. There were marked reductions in the mean F.E.V. ${ }_{0.75}$ and F.V.C. during the shift in all the occupational groups exposed to high concentrations of dust. Byssinotics with chronic bronchitis had a significantly greater mean decrease in F.E. $\mathrm{V}_{\mathbf{0} .75}$ during the shift than the byssinotics without chronic bronchitis, and the workers with neither disease $(\mathbf{P}<0.02)$.

There is no doubt that the dust of Cannabis sativa hemp can cause byssinosis and at least temporary impairment of ventilatory function, varying in severity according to the level of dust exposure and the presence of respiratory disease.

Although increasing attention has been paid in recent years to the effects of vegetable dust on the respiratory system, comparatively little is known about the effects of hemp dust.

There are two distinct types of hemp-hard fibres, which are derived from the leaf of the plant, and soft fibres, derived from the stem. Results from studies of hemp workers are often reported without mention of the type of hemp used, but while it appears to be unlikely that exposure to the dust of hard hemp causes byssinosis there is evidence that exposure to soft hemp may cause the disease.

Werner (1955) in France has described cases of byssinosis from mixed flax and hemp exposure.

Received for publication June I, 1967 .
Stott (1958) and Gilson, Stott, Hopwood, Roach, McKerrow, and Schilling (1962) did not find byssinosis among workers exposed to sisal dust. More recently, Munt, Gauvain, Walford, and Schilling (1965) and McKerrow, Gilson, Schilling, and Skidmore (1965) found no evidence of byssinosis in rope makers exposed to the dust of hard hemp, although there was a slight fall in ventilatory capacity in some cases.

Barbero Carnicero and Flores (1944) and Jiménez Díaz and Lahoz (1944) were the first to describe a condition they called cannabosis in workers exposed to the dust of soft hemp. In a more recent study of soft hemp workers in Spain, it has been shown quite clearly that cannabosis is identical to the disease byssinosis which occurs in cotton and flax workers (Bouhuys, Barbero Carnicero, Lindell, Roach, and Schilling, 1967). 
Velvart, Stravrovská, and Hudáková (1964) suggest that exposure to hemp produces symptoms without the fall of ventilatory capacity during the shift, but it is not clear which type of hemp they studied.

\section{Technological Process}

The raw material in the factory studied is soft hemp (Cannabis sativa) grown in Bačka and Vojvodina (north-east Yugoslavia). The fibres arrive at the factory (Slovenija, Yugoslavia) in bales. In the spinning department they are opened and lubricated on a conveyer belt, cut into lengths, carded, drawn, hackled, and spun (either by dry or wet spinning) into the thread which is collected on bobbins. It is then transported to either the weaving or the rope-making department.

\section{Populations and Methods of Study}

A sample of 93 women and 13 men was studied. It represented $95.5 \%$ of the population (I I I workers) employed in the spinning department. Three women were absent at the time of the study and two women who refused to co-operate fully during respiratory function tests were excluded. Forty-nine workers, 38 women and I I men, employed in other departments of the same factory were examined as controls. They were taken from the departments with average airborne total dust concentrations well below $1 \cdot 0 \mathrm{mg} . / \mathrm{m}^{3}$, and included all workers in these departments with the exception of two women and three men who were absent at the time of the study, and six women who had previously worked in the spinning department.

The workers in the spinning department were classified by occupation into seven working sections. The mean age and length of service in the factory are shown for each section, including controls, in Table I.
None of the women had worked in any other factory, and the men had never been exposed to hemp or any other vegetable dust in previous employment. The mean length of service for both sexes was seven years, but the men were slightly older with a mean age of 34 years compared with 31 for the women. When the two sexes are combined there is some variation between the working sections in mean age and service, the most outstanding being the very short service of the strippers and grinders coupled with a mean age above the general average for all sections, and the relatively long service of the wet spinners.

Respiratory Symptoms and Smoking Habits Work history, the history of past chest diseases, respiratory symptoms, and smoking habits were obtained by means of a modified version of the Medical Research Council questionnaire on respiratory symptoms (Lammers, Schilling, and Walford, r964).

Byssinosis was graded as described by Schilling, Vigliani, Lammers, Valić, and Gilson (1964):

Grade $\frac{1}{2}$ Occasional chest tightness or mild symptoms such as irritation of the respiratory tract on the first day of the working week

Grade I Chest tightness on every first day of the working week

Grade 2 Chest tightness on the first and other days of the working week

Grade 3 Grade 2 symptoms accompanied by evidence of permanent incapacity from diminished effort intolerance.

Chronic bronchitis was defined as persistent cough and phlegm on most days for as much as three months each year during the last two years.

None of the women examined was a smoker, but I I of the men smoked (maximum 15 cigarettes a day), five of them being employed in dusty working sections.

Respiratory Function Tests The forced expiratory volume over 0.75 second (F.E.V .0 .75 ) and the forced vital capacity (F.V.C.) were measured with a

TABLE I

Age and Length of Service by Working Section

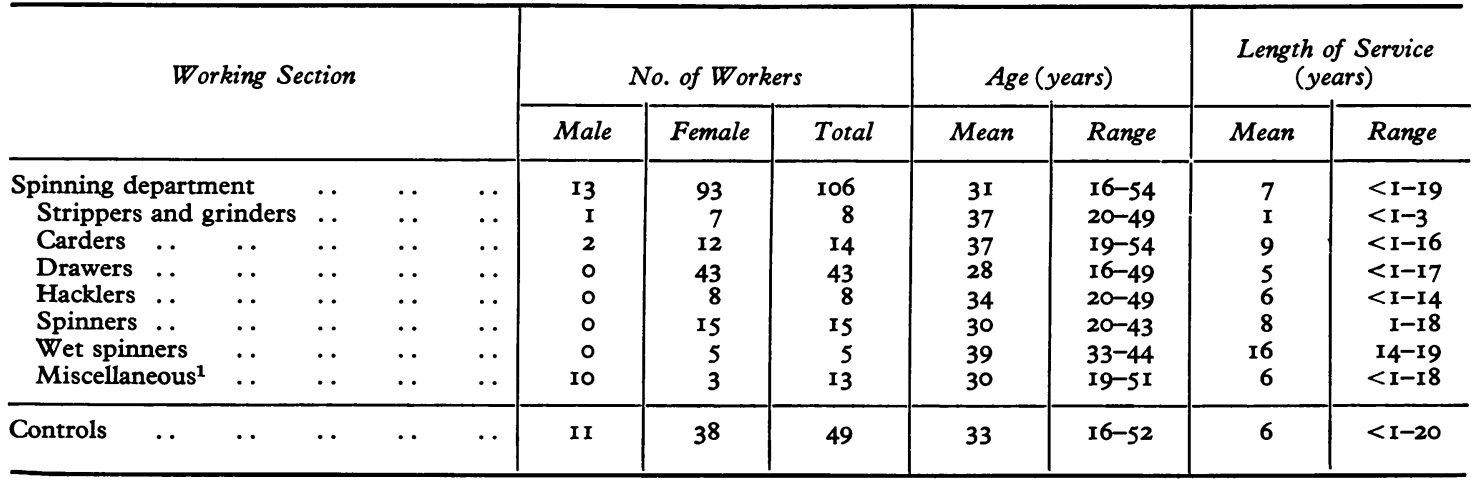

${ }^{1}$ Foremen, supervisors, mechanics, and cleaners. 
direct reading spirometer before the beginning and at the end of the working shift, each worker being tested during the shift he or she was working at the time of the study. The shifts lasted from 6.00 a.m. to 2.00 p.m., 2.00 p.m. to 10.00 p.m., and 10.00 p.m. to 6.00 a.m. All subjects examined had practised the respiratory function tests on a previous occasion.

Determination of Dust Concentrations In most cases the concentration of total airborne dust was measured by using slightly modified (Schilling et al., 1964) M.S.A. Electrostatic Precipitators at the sampling rate of $3 \mathrm{cfm}$ for 4 hours, and the weight of the dust sample was determined from the difference in weight of the collecting electrode before and after sampling. In some cases the filtration method was used, which fully corresponds to the Hexhlet method for total dust (without elutriation). Approximately $6-\mathrm{m}^{3}$ air samples were drawn through weighed Whatman 4I filter papers over periods of 4 hours. The filters with and without the dust sample were weighed at the same humidity level. The two methods of sampling had been proved to give comparable results.

Statistical Analysis Apart from the F.E.V.0.75 and F.V.C. measurements, where an adjustment for sex has been made, it was found that the sex of the worker had no significant influence on the results, and the statistical analysis has been performed on the combined data for men and women. Throughout the analysis the 0.05 level has been used as the criterion of statistical significance.

\section{Results}

Prevalence of Byssinosis and Chronic Bronchitis The sex of the worker did not appear to be an important factor in the development of either byssinosis or chronic bronchitis. In the spinning department, 8 of the 13 men, and 35 of the 93 women, had symptoms of byssinosis, giving a prevalence of $61.5 \%$ for men and $37.6 \%$ for women; further examination suggested that this difference was due solely to the occupational distribution of the men and the data for the two sexes have been combined.

The prevalences of byssinosis and of chronic bronchitis in each working section, together with the results of the airborne dust determinations, are shown in Table II. The exposure of the strippers and grinders was irregular and intermittent, and a meaningful estimate of the level of exposure could not be obtained. However, peak concentrations of total dust were far higher than any other concentrations measured during the study, and the visible dust during their work did not leave much doubt about their exposure level.

Out of a total of 43 byssinotics, consisting of 35 women and 8 men, II women and 3 men were diagnosed as suffering also from chronic bronchitis. Only two workers had symptoms of chronic bronchitis alone; both were women working in the drawing section and were aged 43 and 49 years with 8 and 6 years' service respectively.

The workers in the control group were on the average two years older than those in the spinning department, but none of the controls had symptoms of byssinosis whereas $40.6 \%$ of the workers exposed to dust were found to be suffering from the disease. Similarly, none of the controls was diagnosed as

TABLE II

Prevalence of Byssinosis and Chronic Bronchitis with Mean Age and Length of Service and CONCENTRATION OF Hemp Dust In WORKINg Sections

\begin{tabular}{|c|c|c|c|c|c|c|c|c|c|c|c|c|}
\hline \multirow{2}{*}{\multicolumn{3}{|c|}{ Working Section }} & \multirow{2}{*}{$\begin{array}{l}\text { No. of } \\
\text { Workers }\end{array}$} & \multirow{2}{*}{$\begin{array}{c}\text { Mean } \\
\text { Age } \\
\text { (years) }\end{array}$} & \multirow{2}{*}{$\begin{array}{c}\text { Mean } \\
\text { Length } \\
\text { of Service } \\
\text { (years) }\end{array}$} & \multicolumn{2}{|c|}{$\begin{array}{c}\text { Prevalence of } \\
\text { Byssinosis }\end{array}$} & \multicolumn{2}{|c|}{$\begin{array}{c}\text { Prevalence of } \\
\text { Chronic } \\
\text { Bronchitis }\end{array}$} & \multicolumn{3}{|c|}{ Dust Concentration (mg. $\left./ \mathrm{m}^{3}{ }^{3}\right)$} \\
\hline & & & & & & No. & $\%$ & No. & $\%$ & $\begin{array}{l}\text { No. of } \\
\text { Samples }\end{array}$ & Mean & Range \\
\hline \multicolumn{3}{|c|}{$\begin{array}{l}\text { Spinning department } \ldots \\
\text { Strippers and grinders }\end{array}$} & $\begin{array}{r}106 \\
8\end{array}$ & $\begin{array}{l}3 \mathrm{I} \\
37\end{array}$ & $\begin{array}{l}7 \\
1\end{array}$ & $\begin{array}{r}43 \\
4\end{array}$ & $\begin{array}{l}40 \cdot 6 \\
50 \cdot 0\end{array}$ & $\begin{array}{r}16 \\
1\end{array}$ & $\begin{array}{l}15 \cdot 1 \\
12 \cdot 5\end{array}$ & & \multicolumn{2}{|c|}{ Not measured ${ }^{2}$} \\
\hline Carders & $\ldots$ & .. & 14 & 37 & 9 & 8 & $57 \cdot 1$ & 5 & $35 \cdot 7$ & 27 & $19 \cdot 5$ & $6 \cdot 0-53 \cdot 3$ \\
\hline Drawers & .. & .. & 43 & 28 & 5 & 13 & $30 \cdot 2$ & 4 & $9 \cdot 3$ & 15 & $8 \cdot 1$ & $5 \cdot 3-11 \cdot 9$ \\
\hline Hacklers & .. & $\ldots$ & 8 & 34 & 6 & 5 & $62 \cdot 5$ & 2 & $25 \cdot 0$ & 15 & $7 \cdot 9$ & $5 \cdot 7-11 \cdot 4$ \\
\hline Spinners & $\ldots$ & . & 15 & 30 & 8 & 6 & $40 \cdot 0$ & 2 & $13 \cdot 3$ & 17 & $6 \cdot 8$ & $2 \cdot 6-15 \cdot 3$ \\
\hline Wet spinners & & . & 5 & 39 & 16 & I & $20 \cdot 0$ & $\circ$ & - & 4 & $2 \cdot 9$ & I. $3-5 \cdot 0$ \\
\hline Miscellaneou & & . & 13 & 30 & 6 & 6 & $46 \cdot 2$ & 2 & $15 \cdot 4$ & & Not $\mathrm{r}$ & easured \\
\hline Controls & . & . & 49 & 33 & 6 & ० & - & $\circ$ & - & & $<\mathbf{I} \cdot \mathbf{0}$ & - \\
\hline
\end{tabular}

${ }^{1}$ Irregular exposure made it impossible to obtain a meaningful estimate of the level of exposure, but peak concentrations of total dust were far higher than any other concentrations measured during the study. 
suffering from chronic bronchitis compared with a prevalence of $15.1 \%$ in the spinning department. For each disease the probability of such a difference in prevalence occurring by chance would be less than 0.003 .

The association between byssinosis and chronic bronchitis was examined in the workers in the spinning department by comparing the prevalence of chronic bronchitis among the byssinotics $(32 \cdot 6 \%)$ with that among the non-byssinotics $(3 \cdot 2 \%)$. Since the workers without byssinosis were on the average younger than the byssinotics, the difference between the two groups in the proportion of workers with chronic bronchitis was calculated separately for four age groups. To allow for variation in the size of the subgroups, each difference was weighted by the factor $n_{1} n_{2} / n_{1}+n_{2}$, where $n_{1}$ and $n_{2}$ were the number of workers in each subgroup. The mean weighted difference was tested and the excess of chronic bronchitis in the byssinotics found to be statistically significant $(\mathbf{P}<0.001)$.

Comparisons of Byssinosis Prevalence among Working Sections When the prevalence of byssinosis among the seven occupational groups in the spinning department was examined in detail, the most important factor associated with the prevalence of byssinosis was length of service in a dusty occupation. A positive association with increasing age became negligible when length of service was held constant.

The average length of service varied considerably among the working sections, but the numbers of workers in the individual sections were too small to enable a further breakdown of the data to be made in order to standardize for length of service by the methods usually employed in the comparison of prevalence rates. Nevertheless, to compare the risk of byssinosis among the occupational groups in the spinning department it was necessary to make some adjustment to allow for variation in length of service. Consequently, byssinosis was scored on a two-point scale, with a value of I when the disease was present and $o$ when it was absent, and the prevalence rate in each section was adjusted by the regression of byssinosis on length of service. ${ }^{1}$

A linear relationship was first considered but, when the workers were grouped by length of service, although the prevalence of byssinosis among those employed for less than ro years rose rapidly as length of service increased, this trend

\footnotetext{
${ }^{1}$ When the dependent variable takes only the values $O$ and $I$ the classical method of regression analysis is not ideal, but transformation of the variable to the probit or logistic form was not helpful.
}

was less marked in the groups with longer service (Table III). This suggested that the relationship

TABLE III

Prevalence of Byssinosis in the Spinning Department, BY LENGTH OF SERVICE

\begin{tabular}{c|c|c|c}
\hline \multirow{2}{*}{$\begin{array}{c}\text { Length of Service } \\
\text { (years) }\end{array}$} & \multicolumn{2}{|c|}{$\begin{array}{c}\text { No. of } \\
\text { Workers }\end{array}$} & \multicolumn{2}{|c}{ Byssinosis Prevalence } \\
\cline { 3 - 4 } & & No. & $\%$ \\
\hline Less than I & 17 & 3 & $17 \cdot 6$ \\
I- & 6 & 1 & $16 \cdot 7$ \\
$2-4$ & 27 & 10 & $37 \cdot 0$ \\
$5-9$ & 25 & 13 & $52 \cdot 0$ \\
I0-14 & 17 & 8 & $47 \cdot 1$ \\
I5-19 & 14 & 8 & $57 \cdot 1$ \\
\hline All workers & 106 & 43 & $40 \cdot 6$ \\
& & & \\
\hline
\end{tabular}

between byssinosis prevalence and length of service might be best described by a second-degree curve. Equations of the form $y=a+b_{1} x_{1}+b_{2} x_{2}$ were derived for each working section by the ordinary method of multiple regression, putting $x_{1}=x$ and $x_{2}=x^{2}$, where $x$ is length of service in years. The regression coefficients showed no statistically significant differehces between the working sections, and a common curve $y=0.163+0.058 x-$ $0.0018 x^{2}$ was fitted to the pooled data. The regression coefficients can be interpreted as the average proportional change in byssinosis prevalence associated with each year of service.

The proportion of byssinotics in each working section was adjusted to give the proportion expected if workers in each section had been employed for seven years. The adjusted values expressed as percentages are shown in Table IV. An overall test of the differences between the adjusted proportions showed that these were not statistically significant. Nevertheless, in view of the relationship between the level of dust concentration and byssinosis found in other studies, it was considered permissible to compare the two sections known to be exposed to high dust concentrations (the strippers and grinders and the carders) with each of the other dust-exposed sections, and to compare the low dust concentration section of wet spinners with each of the medium exposure sections of drawers, hacklers, and spinners. Of these comparisons the only two differences that were statistically significant at the 0.05 level were between wet spinners and strippers and grinders, and between wet spinners and hacklers.

Severity of Byssinosis and the Complication of Chronic Bronchitis The byssinotics in each 
TABLE IV

Byssinosis Prevalence in the Spinning Department AdJUSTEd FOR LENGTH OF SERVICE

\begin{tabular}{l|c}
\hline Working Section & $\begin{array}{c}\text { Prevalence of Byssinosis } \\
\text { Adjusted for Length of } \\
\text { Service } \\
(\%)\end{array}$ \\
\hline Strippers and grinders & $66 \cdot 5$ \\
Carders & $48 \cdot 6$ \\
Drawers & $33 \cdot 4$ \\
Hacklers & $63 \cdot 4$ \\
Spinners & $35 \cdot 0$ \\
Wet spinners & $-0 \cdot 2$ \\
Miscellaneous & $47 \cdot 5$ \\
\hline
\end{tabular}

Significant differences between adjusted percentages Wet spinners $v$. strippers and grinders $\quad P<0.05$ Wet spinners $v$. hacklers $\mathbf{P}<0.05$

working section were classified by grade of severity of the disease and by the presence or absence of chronic bronchitis. The numbers in the subgroups were very small, but the hackling section not only had the highest proportion of byssinotics but also the highest proportion of severe cases, with two out of the five byssinotics classified as grade 2 and one as grade 3. The carding section had the highest proportion of byssinotics with chronic bronchitis: five of the eight workers with byssinosis also had chronic bronchitis.

In the combined spinning department the severity of byssinosis did not appear to be positively associated with either age or length of service, but when workers with byssinosis and chronic bronchitis are compared with those with byssinosis only and with workers with neither disease, both mean age and mean length of service show a slight positive trend with increasing chest symptoms (Table V).

There was no positive association between the severity of byssinosis and the presence of chronic bronchitis. Among the grade $\frac{1}{2}$ byssinotics $40 \%$ had chronic bronchitis, compared with $31 \%$ of those with grade I byssinosis and $33 \%$ of those with grades 2 or 3 .

Time of Shift and Ventilatory Capacity Investigations in cotton mills and in non-dusty factories in Holland, employing a three-shift system, have shown that the F.E.V ${ }_{\cdot 0.75}$ of workers without byssinosis increases slightly during the morning shift but decreases quite appreciably during the afternoon and night shifts (Walford, Lammers, Schilling, van den Hoven van Genderen, and van der Veen, 1966).

Examination of the data by working section and
TABLE V

Byssinosis Prevalence, Mean Age, and Mean Length of SERvice, IN WORKers IN THE SPINNING Department, by Grade of Byssinosis and the Presence or Absence OF CHRONIC BRONCHITIS

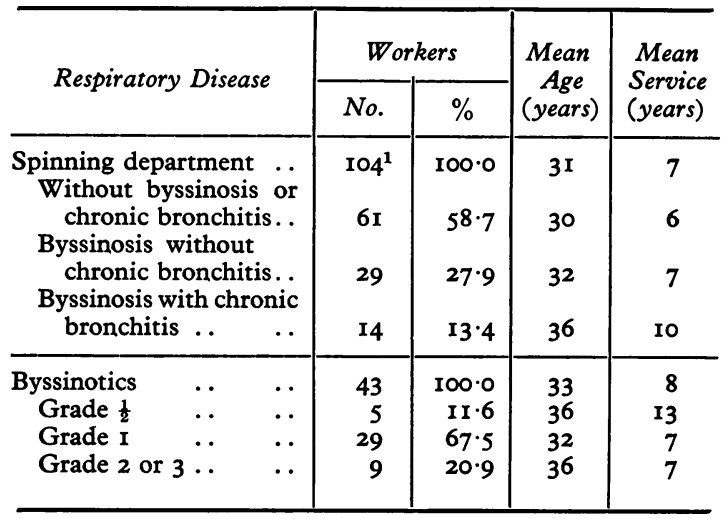

${ }^{1}$ Excluding two women with chronic bronchitis only.

time of shift showed no evidence of an association between the time of the shift and the mean change in F.E.V. $\cdot_{\mathbf{0 . 7 5}}$ or F.V.C. during the shift. With such small numbers, and the need to allow for several concomitant variables, it was not possible to examine adequately the F.E.V. $\cdot_{0.75}$ and F.V.C. measured at the beginning of the shift, but there were no obvious differences between the shifts.

\section{Long-term Effects of Exposure to Hemp Dust on Ventilatory Function}

Comparison of F.E.V $\cdot_{\mathbf{0 . 7 5}}$ and F.V.C. in Working Sections To assess the long-term effects of exposure to hemp dust on the ventilatory function of the lung, the F.E.V $\cdot_{0.75}$ and F.V.C. measurements taken at the beginning of the working shift were examined. It was not possible to make separate comparisons between working sections for each sex since only a small proportion of the workers were men, and they were employed mainly in the miscellaneous and control sections.

Both the F.E.V $\cdot_{0.75}$ and F.V.C. are known to be related to the sex, age, and height of the subject, and it was necessary to adjust the observed mean values in each section to allow for these factors before making comparisons. Since the differences between the two sexes in the partial regression coefficients of F.E.V $\cdot_{\cdot 0.75}$ and F.V.C. on age and on sitting height were small and not statistically significant, it was possible to compare the working sections by adjusting the mean F.E.V $\cdot_{0.75}$ and F.V.C. by the regression on age, sitting height, and 
TABLE VI

Mean F.E.V.0.75 AND Mean F.V.C. Before Work, Adjusted for Age, Sitting Height, and Sex

\begin{tabular}{|c|c|c|c|c|c|c|c|c|}
\hline \multirow[b]{2}{*}{ Working Section } & \multirow[b]{2}{*}{$\begin{array}{c}\text { Total No. } \\
\text { of } \\
\text { Workers }\end{array}$} & \multirow[b]{2}{*}{$\begin{array}{c}\text { Male } \\
\text { Workers } \\
(\%)\end{array}$} & \multirow[b]{2}{*}{$\begin{array}{c}\text { Mean } \\
\text { Age } \\
\text { (years) }\end{array}$} & \multirow[b]{2}{*}{$\begin{array}{c}\text { Mean } \\
\text { Sitting } \\
\text { Height } \\
(\mathrm{cm} .)\end{array}$} & \multicolumn{2}{|c|}{ Mean F.E.V. $\cdot_{\cdot 0 \cdot 75}$ (litres) } & \multicolumn{2}{|c|}{ Mean F.V.C. (litres) } \\
\hline & & & & & Unadjusted & $\begin{array}{l}\text { Adjusted } \\
\text { for Age, } \\
\text { Sitting } \\
\text { Height, } \\
\text { and Sex }\end{array}$ & Unadjusted & $\begin{array}{c}\text { Adjusted } \\
\text { for Age, } \\
\text { Sitting } \\
\text { Height, } \\
\text { and Sex }\end{array}$ \\
\hline \begin{tabular}{lll} 
Spinning department &.. \\
Strippers & and & \multicolumn{2}{c}{ grinders } \\
Carders &.. &.. \\
Drawers &.. & $\ldots$ \\
Hacklers &.. & $\ldots$ \\
Spinners &.. & $\ldots$ \\
Wet spinners &.. & $\ldots$ \\
Miscellaneous & &..
\end{tabular} & $\begin{array}{r}106 \\
8 \\
14 \\
43 \\
8 \\
15 \\
5 \\
13\end{array}$ & $\begin{array}{r}12 \cdot 3 \\
12 \cdot 5 \\
14 \cdot 3 \\
0 \\
0 \\
0 \\
0 \\
76 \cdot 9\end{array}$ & $\begin{array}{l}31 \\
37 \\
37 \\
28 \\
34 \\
30 \\
39 \\
30\end{array}$ & $\begin{array}{l}82 \cdot 7 \\
81 \cdot 5 \\
83 \cdot 5 \\
82 \cdot 0 \\
81 \cdot 5 \\
82 \cdot 5 \\
81 \cdot 5 \\
86 \cdot 5\end{array}$ & $\begin{array}{l}2 \cdot 49 \\
2 \cdot 65 \\
2 \cdot 36 \\
2 \cdot 53 \\
2 \cdot 18 \\
2 \cdot 41 \\
2 \cdot 05 \\
2 \cdot 85\end{array}$ & $\begin{array}{l}2 \cdot 51 \\
2 \cdot 83 \\
2 \cdot 43 \\
2 \cdot 57 \\
2 \cdot 35 \\
2 \cdot 46 \\
2 \cdot 31 \\
2 \cdot 44\end{array}$ & $\begin{array}{l}3 \cdot 27 \\
3 \cdot 42 \\
3 \cdot 25 \\
3 \cdot 20 \\
3 \cdot 00 \\
3 \cdot 26 \\
2 \cdot 71 \\
3 \cdot 86\end{array}$ & $\begin{array}{l}3 \cdot 31 \\
3 \cdot 62 \\
3 \cdot 29 \\
3 \cdot 32 \\
3 \cdot 20 \\
3 \cdot 37 \\
3 \cdot 01 \\
3 \cdot 23\end{array}$ \\
\hline Controls .. & 49 & $22 \cdot 4$ & 33 & $83 \cdot 5$ & $2 \cdot 53$ & $2 \cdot 49$ & $3 \cdot 30$ & $3 \cdot 22$ \\
\hline
\end{tabular}

${ }^{1}$ Adjusted to standard given by spinning department and controls combined, i.e., $15.5 \%$ males, mean age 32 years, mean sitting height $83 \mathrm{~cm}$.

To obtain adjusted mean F.E.V.0.75 for women alone subtract 0.062 litre; for men alone add 0.336 litre.

To obtain adjusted mean F.V.C. for women alone subtract 0.094 litre; for men alone add 0.51 I litre.

sex. Sex was quantified by giving a score of $o$ to the women and a score of $I$ to the men. The regression coefficient for sex represents the average difference in ventilatory capacity between men and women after adjustment for age and sitting height. Length of service in dusty occupations was also considered as a possible factor influencing the F.E.V $\cdot_{\cdot 0.75}$ and F.V.C., but the association proved to be negligible when age, sitting height, and sex were held constant.

For both F.E.V $\cdot_{0.75}$ and F.V.C. the partial regression coefficients did not differ significantly between working sections, and the data were pooled to give the regression of F.E.V. ${ }_{\cdot 0.75}$ on age independent of sitting height and sex as $b_{1}=-0.018$ litre per year, the regression on sitting height independent of age and sex as $b_{2}=0.042$ litre per $\mathrm{cm}$., and the regression on sex independent of age and sitting height as $b_{3}=0.398$ litre. Partial regression coefficients for F.V.C. were $b_{1}=-0.012$ litre per year, $b_{2}=0.071$ litre per $\mathrm{cm}$., and $b_{3}=0.605$ litre. All these regression coefficients were statistically significant at the $0.00 \mathrm{r}$ level.

The mean of the observed F.E.V $\cdot_{0.75}$ and F.V.C. and the adjusted values are shown for each working section in Table VI. For both F.E.V.0.75 and F.V.C. an overall test of the differences between the adjusted means of the sections showed that these were not statistically significant. It was still permissible to compare the control group with each of the other occupational groups, but the only statistically significant differences found were between controls and strippers and grinders, where the strippers and grinders unexpectedly had both a higher F.E.V .0.75 than the controls, with a difference of 0.335 litre $(\mathbf{P}<0.02)$, and a higher F.V.C., with a difference of 0.402 litre $(\mathrm{P}<0.01)$.

Comparison of F.E.V. $\cdot_{0.75}$ and F.V.C. between Workers Classified by Respiratory Disease Since the mean F.E.V.0.75 and F.V.C. found in the working sections did not appear to be related to the level of dust concentration the eight sections were combined, and the workers were divided into those without byssinosis or chronic bronchitis, byssinotics without chronic bronchitis, and byssinotics with chronic bronchitis. The two women in the drawing section who had chronic bronchitis but not byssinosis were excluded.

An attempt was made to compare the three groups after adjusting the mean F.E.V $\cdot_{0.75}$ and F.V.C. for age, sitting height, and sex, but for both F.E.V.0.75 and F.V.C. the partial regression coefficients, calculated separately for each symptom group, differed significantly between the groups. It would have been incorrect to derive one set of coefficients to represent the whole data, and to avoid the difficulties of interpretation that arise with heterogeneous regression coefficients it was decided to use the ratio F.E.V.0.75/F.V.C. This provided a more specific index of expiratory viscous resistance than the F.E.V .0.75 alone and had the advantage of being independent of height and sex. 
Comparison of F.E.V $\cdot_{0.75} / F . V . C$. Ratio between Working Sections For each individual the F.E.V.0.75 measured at the beginning of the working shift was expressed as a percentage of the F.V.C. measured at the same time. Examination within working sections showed that the F.E.V. ${ }_{\cdot 0.75} /$ F.V.C. ratio was independent of height, and although it tended to be slightly lower for males the partial regression on sex independent of age was small and not statistically significant. Therefore, only the simple linear relationship with age has been considered.

Regression coefficients for age were calculated for each working section and found to be homogeneous. The data were then pooled to give an estimate of the regression of F.E.V $\cdot_{0.75} /$ F.V.C. on age as $b=-0.278 \%$.

The mean ratios for each working section, before and after adjustment for age, are shown in Table VII. An overall test of the differences between the adjusted mean ratios showed that these were not statistically significant, and when the controls were compared with each of the other sections it was found that all the differences could be attributed to sampling error.

Comparison of F.E.V $\cdot_{\cdot 0.75} / F . V . C$. Ratio between Workers Classified by Respiratory Disease The F.E.V ${ }_{\cdot 0.75} / F$.V.C. ratio was examined in the three respiratory disease groups: workers without byssinosis or chronic bronchitis, byssinotics without chronic bronchitis, and byssinotics with chronic bronchitis.

TABLE VII

MEAN F.E.V.0.75/F.V.C. BEFORE WORK, ADJUSTED FOR AGE

\begin{tabular}{|c|c|c|c|c|}
\hline \multirow[b]{2}{*}{ Working Section } & \multirow[b]{2}{*}{$\begin{array}{l}\text { No. of } \\
\text { Workers }\end{array}$} & \multirow{2}{*}{$\begin{array}{c}\text { Mean } \\
\text { Age } \\
\text { (years) }\end{array}$} & \multicolumn{2}{|c|}{$F . E . V_{\cdot 0 \cdot 75} / F . V . C}$. \\
\hline & & & $\begin{array}{c}\text { Unadjusted } \\
\qquad(\%)\end{array}$ & $\begin{array}{c}\text { Adjusted } \\
\text { for Age } 1 \\
\quad(\%)\end{array}$ \\
\hline $\begin{array}{lc}\begin{array}{c}\text { Spinning } \\
\text { department } \\
\begin{array}{c}\text { Strippers } \\
\text { grinders }\end{array}\end{array} \text { and } \\
\text { Carders } & \ldots \\
\text { Drawers } & \ldots \\
\text { Hacklers } & \ldots \\
\text { Spinners } & \ldots \\
\text { Wet spinners.. } \\
\text { Miscellaneous }\end{array}$ & $\begin{array}{r}106 \\
\\
8 \\
14 \\
43 \\
8 \\
15 \\
5 \\
13\end{array}$ & $\begin{array}{l}31 \\
37 \\
37 \\
28 \\
34 \\
30 \\
39 \\
30\end{array}$ & $\begin{array}{l}76 \cdot 3 \\
77 \cdot 5 \\
72 \cdot 9 \\
79 \cdot 0 \\
73 \cdot 2 \\
74 \cdot 1 \\
75 \cdot 5 \\
74 \cdot 6\end{array}$ & $\begin{array}{l}76 \cdot 1 \\
79 \cdot 0 \\
74 \cdot 3 \\
78 \cdot 0 \\
73 \cdot 9 \\
73 \cdot 6 \\
77 \cdot 4 \\
74 \cdot 1\end{array}$ \\
\hline Controls & 49 & 33 & $77 \cdot 2$ & $77 \cdot 4$ \\
\hline
\end{tabular}

${ }^{1}$ Expected mean value for workers with a mean age of 32 years.
The regression of F.E.V ${ }_{\cdot 0.75} /$ F.V.C. on age was similar in the three groups, and the pooled data gave a common regression coefficient of $\mathrm{b}=-0.26 \mathrm{I} \%$. The unadjusted mean ratios as well as the age-adjusted values show a steady decrease with each additional respiratory disease (Table VIII). However, the only statistically significant difference in the adjusted mean F.E.V.0.75 F.V.C. was between the byssinotics with chronic bronchitis and the workers with neither disease $(P<0.05)$; the mean ratio for the byssinotics was smaller by $4.9 \%$.

\section{TABLE VIII}

MEAN F.E.V.0.75/F.V.C. BEFORE WORK, ADJUSTED FOR AGE, IN BYsSINOTICS WITH CHRONIC BRONCHITIS, Byssinotics without CHRONIC BRONCHITIS, AND WORKERS WITHOUT BYSSINOSIS OR CHRONIC BRONCHITIS

\begin{tabular}{|c|c|c|c|c|}
\hline \multirow[b]{2}{*}{ Symptom Group } & \multirow[b]{2}{*}{$\begin{array}{c}\text { No. of } \\
\text { Workers }\end{array}$} & \multirow{2}{*}{$\begin{array}{c}\text { Mean } \\
\text { Age } \\
\text { (years) }\end{array}$} & \multicolumn{2}{|c|}{ F.E.V. ${ }_{\cdot 0 \cdot 75} / F . V . C}$. \\
\hline & & & $\begin{array}{c}\text { Un- } \\
\text { adjusted } \\
(\%)\end{array}$ & $\begin{array}{c}\text { Adjusted } \\
\text { for Age } 1 \\
(\%)\end{array}$ \\
\hline $\begin{array}{l}\text { Without byssinosis or } \\
\text { chronic bronchitis } \\
\text { Byssinosis without } \\
\text { chronic bronchitis } \\
\text { Byssinosis with } \\
\text { chronic bronchitis }\end{array}$ & 29 & $\begin{array}{l}31 \\
32 \\
36\end{array}$ & $\begin{array}{l}77 \cdot 7 \\
75 \cdot 2 \\
71 \cdot 5\end{array}$ & $\begin{array}{l}77 \cdot 5 \\
75 \cdot 4 \\
72 \cdot 6\end{array}$ \\
\hline
\end{tabular}

${ }^{1}$ Expected mean value for workers with a mean age of 32 years.

Miller, Johnson, and Wu (1959), using a GaenslerCollins timed vitalometer, measured the forced vital capacity and $0.75 \mathrm{sec}$. timed expiratory capacity of 77 men and 76 women aged 20 to 59 years with no history of pulmonary or cardiac disease. The mean F.E.V $\cdot_{0.75} /$ F.V.C. was found to be $77.3 \%$ with no difference between the sexes. Only $5 \%$ of the subjects were found to have a ratio lower than $70 \%$ and this value was accepted as a satisfactory lower limit of normal.

If the three respiratory disease groups in this study are examined, using a ratio of $70 \%$ as a critical value, $7(50 \%)$ of the byssinotics with chronic bronchitis, $8(28 \%)$ without chronic bronchitis, and $19(17 \%)$ of the workers with neither disease fell below the normal limit.

Acute Effects of Exposure to Hemp Dust on Ventilatory Capacity The changes in F.E.V $\cdot_{0.75}$ and F.V.C. during the working shift have been used to assess the acute effects of exposure to hemp dust on ventilatory capacity.

Preliminary examination of the data suggested 
that for both measures of lung function the amount of decrease during the shift was associated with dust exposure and the presence of byssinosis and chronic bronchitis. There was no evidence of any association with age, sex, or the time of the shift.

Comparison between Working Sections of the Change in F.E.V $\cdot_{0.75}$ and F.V.C. during the Shift The mean change in F.E.V $\cdot_{0.75}$ and F.V.C. during the shift was calculated for each working section (Table IX). Only the wet spinners showed an

\section{TABLE IX}

Mean Change in F.E.V.0.75 AND F.V.C. duRING The SHIFT BY WORKING SECTIONS

\begin{tabular}{|c|c|c|c|}
\hline Working Sections & $\begin{array}{c}\text { No. of } \\
\text { Workers }\end{array}$ & $\begin{array}{c}\text { Mean } \\
\text { Change } \\
\text { in } \begin{array}{c}F . E . V_{\cdot 0 \cdot 75} \\
\text { (litres) }\end{array}\end{array}$ & $\begin{array}{c}\text { Mean } \\
\text { Change } \\
\text { in F.V.C. } \\
\text { (litres) }\end{array}$ \\
\hline $\begin{array}{lll}\text { Spinning department } & \text {.. } \\
\text { Strippers and } & \text { grinders } \\
\text { Carders } & . . & . . \\
\text { Drawers } & . & . . \\
\text { Hacklers } & . & . . \\
\text { Spinners } & . & . . \\
\text { Wet spinners .. } & \ldots \\
\text { Miscellaneous } & \ldots\end{array}$ & $\begin{array}{r}106 \\
8 \\
14 \\
43 \\
8 \\
15 \\
5 \\
13\end{array}$ & $\begin{array}{l}-0.36 \\
-0.57 \\
-0.45 \\
-0.37 \\
-0.37 \\
-0.34 \\
+0.14 \\
-0.28\end{array}$ & $\begin{array}{l}-0.43 \\
-0.65 \\
-0.54 \\
-0.45 \\
-0.51 \\
-0.41 \\
+0.14 \\
-0.28\end{array}$ \\
\hline Controls.. & 49 & -0.11 & -0.14 \\
\hline
\end{tabular}

average rise for both measures of ventilatory capacity. All other sections, including the controls, showed a considerable mean decrease in both F.E.V ${ }_{\cdot 0.75}$ and F.V.C. which becomes more marked in the sections most highly exposed to hemp dust.

Differences in mean change between the working sections were examined by an analysis of variance and found to be statistically significant at the $0.00 \mathrm{I}$ level for both F.E.V.0.75 and F.V.C. Individual comparisons between pairs of sections showed several differences to be statistically significant (Table X). The general tendency of the F.E.V.0.75 and F.V.C. of the wet spinners to increase during the shift led to significant differences between this section and all other sections, including the controls. In both measures of ventilatory capacity the controls had a smaller mean decrease during the shift than the strippers and grinders, carders, hacklers, drawers, and spinners; the strippers and grinders had a greater mean decrease than the miscellaneous workers, the spinners and the drawers.

Comparisons between Respiratory Disease Groups of the Change in F.E.V.0.75 and F.V.C. during the
Shift The workers were again divided into byssinotics with chronic bronchitis, byssinotics without chronic bronchitis, and workers with neither disease. Since the change in ventilatory capacity during the shift was associated with the level of dust exposure the mean change in F.E.V.0.75 and F.V.C. was calculated for each working section within the three disease groups (Table XI). Comparisons were then made by calculating separately for each working section the difference between the disease groups in the mean change in F.E.V.0.75 and F.V.C. and weighting it by the factor $n_{1} n_{2} / n_{1}+n_{2}$, where $n_{1}$ and $n_{2}$ are the numbers in each working section. Since there were no byssinotics among the controls and only one among the wet spinners, these two sections were excluded. A mean weighted difference, calculated over the six remaining sections, was tested for significance.

Statistically significant differences in the change in F E.V..$_{0.75}$ were found between byssinotics with chronic bronchitis and byssinotics without chronic bronchitis $(P<0.02)$, and between byssinotics with chronic bronchitis and workers with neither disease $(P<0.02)$.

There were no statistically significant differences between any of the groups in the mean change in F.V.C. during the shift.

Change in F.E.V $\cdot_{0.75}$ and F.V.C. during the Shift and Severity of Byssinosis The eight sections were combined and the workers were classified by byssinosis grade and the presence or absence of chronic bronchitis. In spite of very small numbers, both the F.E.V $\cdot_{0.75}$ and the F.V.C. show a mean reduction during the shift that tends to increase in magnitude as the severity of byssinosis increases (Table XII). The numbers were too small to allow examination within individual working sections, and no statistical tests were carried out.

\section{Discussion}

From the results obtained in this survey there is no doubt that byssinosis exists among workers exposed to Cannabis sativa hemp dust. Among the I06 workers who had been exposed to hemp dust in the spinning department, $43(40 \cdot 6 \%)$ were diagnosed as suffering from byssinosis, while not one of the 49 controls had the disease. The prevalence of byssinosis increased with length of service in dusty occupations; for the combined spinning department workers the relationship could be described by the second degree curve $y=0.163+0.058 x-$ $0.0018 x^{2}$, where $y$ is byssinosis prevalence expressed as a proportion and $x$ is length of service in years. This equation merely describes the 
TABLE X

Statistically Significant Differences between Working Sections in Mean Change in F.E.V.0.75 ANd/OR F.V.C. DURING THE SHIFT

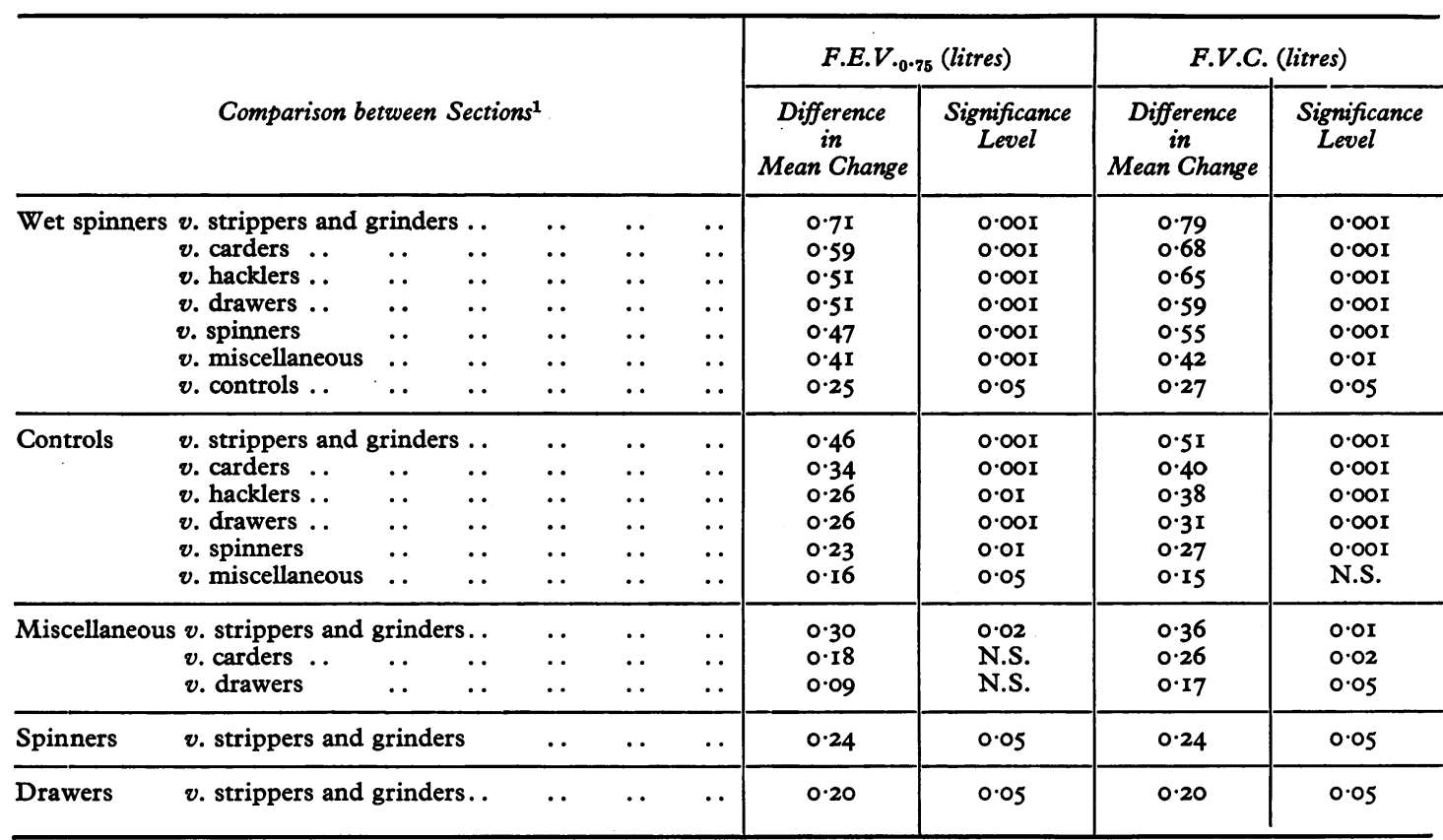

${ }^{1}$ Section showing a greater decrease of F.E.V.0.75 and/or F.V.C. is shown on the right-hand side.

N.S. $=\mathbf{P}>0.05$.

TABLE XI

Mean Change in F.E.V.0.75 and F.V.C. DURING the Shift, in Byssinotics with Chronic Bronchitis, Byssinotics WI ThOUT CHRONIC BRONCHITIS, AND WORKERS WITHOUT BYSSINOSIS OR CHRONIC BRONCHITIS

\begin{tabular}{|c|c|c|c|c|c|c|c|c|c|c|}
\hline \multirow{3}{*}{\multicolumn{2}{|c|}{ Working Section }} & \multicolumn{3}{|c|}{$\begin{array}{l}\text { Without Byssinosis } \\
\text { or Chronic Bronchitis }\end{array}$} & \multicolumn{3}{|c|}{$\begin{array}{l}\text { Byssinosis without } \\
\text { Chronic Bronchitis }\end{array}$} & \multicolumn{3}{|c|}{$\begin{array}{l}\text { Byssinosis with } \\
\text { Chronic Bronchitis }\end{array}$} \\
\hline & & \multirow{2}{*}{$\begin{array}{c}\text { No. of } \\
\text { Workers }\end{array}$} & \multicolumn{2}{|c|}{ Mean Change (litres) } & \multirow{2}{*}{$\begin{array}{l}\text { No. of } \\
\text { Workers }\end{array}$} & \multicolumn{2}{|c|}{ Mean Change (litres) } & \multirow{2}{*}{$\begin{array}{l}\text { No. of } \\
\text { Workers }\end{array}$} & \multicolumn{2}{|c|}{ Mean Change (litres) } \\
\hline & & & F.E.V. $\cdot_{0.75}$ & F.V.C. & & F.E.V.V.0.75 & F.V.C. & & F.E.V.V.0.75 & F.V.C. \\
\hline $\begin{array}{l}\text { Spinning depart } \\
\text { Strippers and g } \\
\text { Carders } \\
\text { Drawers } \quad . \\
\text { Hacklers } \quad . \\
\text { Spinners . } \\
\text { Wet spinners } \\
\text { Miscellaneous }\end{array}$ & $\begin{array}{l}\text { ters } \\
\ldots \\
\ldots \\
\ldots \\
\ldots \\
\ldots\end{array}$ & $\begin{array}{c}6 \mathrm{I}^{1} \\
4 \\
6 \\
28^{1} \\
3 \\
9 \\
4 \\
7\end{array}$ & $\begin{array}{l}-0.32 \\
-0.48 \\
-0.39 \\
-0.35 \\
-0.32 \\
-0.30 \\
+0.11 \\
-0.34\end{array}$ & $\begin{array}{l}-0.38 \\
-0.58 \\
-0.40 \\
-0.42 \\
-0.43 \\
-0.40 \\
+0.17 \\
-0.35\end{array}$ & $\begin{array}{r}29 \\
3 \\
3 \\
11 \\
3 \\
4 \\
1 \\
4\end{array}$ & $\begin{array}{l}-0.34 \\
-0.73 \\
-0.21 \\
-0.44 \\
-0.23 \\
-0.28 \\
+0.25 \\
-0.13\end{array}$ & $\begin{array}{l}-0.44 \\
-0.76 \\
-0.46 \\
-0.54 \\
-0.38 \\
-0.38 \\
+0.01 \\
-0.12\end{array}$ & $\begin{array}{r}14 \\
1 \\
5 \\
2 \\
2 \\
2 \\
0 \\
2\end{array}$ & $\begin{array}{l}-0.56 \\
-0.45 \\
-0.70 \\
-0.42 \\
-0.67 \\
-0.61 \\
-0.33\end{array}$ & $\begin{array}{l}-0.59 \\
-0.55 \\
-0.75 \\
-0.33 \\
-0.84 \\
-0.47 \\
-0.36\end{array}$ \\
\hline Controls & $\cdots$ & 49 & -0.11 & -0.14 & 0 & - & - & 0 & - & - \\
\hline
\end{tabular}

${ }^{1}$ Excludes two women with chronic bronchitis only. 
TABLE XII

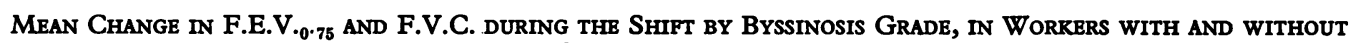
Chronic Bronchitis

\begin{tabular}{|c|c|c|c|c|c|c|}
\hline \multirow{2}{*}{$\begin{array}{c}\text { Byssinosis } \\
\text { Grade }\end{array}$} & \multicolumn{3}{|c|}{ With Chronic Bronchitis } & \multicolumn{3}{|c|}{ Without Chronic Bronchitis } \\
\hline & $\begin{array}{c}\text { No. of } \\
\text { Workers }\end{array}$ & $\begin{array}{c}\text { Mean Change } \\
\text { in F.E.V. } \cdot 0 \cdot 75 \\
\text { (litres) }\end{array}$ & $\begin{array}{c}\text { Mean Change } \\
\text { in F.V.C. } \\
\text { (litres) }\end{array}$ & $\begin{array}{c}\text { No. of } \\
\text { Workers }\end{array}$ & $\begin{array}{l}\text { Mean Change } \\
\text { in F.E.V.V·0·75 } \\
\quad \text { (litres) }\end{array}$ & $\begin{array}{c}\text { Mean Change } \\
\text { in F.V.C. } \\
\text { (litres) }\end{array}$ \\
\hline $\begin{array}{l}0 \\
\frac{1}{2} \\
1 \\
2 \text { or } 3\end{array}$ & $\begin{array}{l}2 \\
2 \\
9 \\
3\end{array}$ & $\begin{array}{l}-0.19 \\
-0.47 \\
-0.53 \\
-0.72\end{array}$ & $\begin{array}{l}-0.40 \\
-0.52 \\
-0.50 \\
-0.93\end{array}$ & $\begin{array}{r}110 \\
3 \\
20 \\
6\end{array}$ & $\begin{array}{l}-0.23 \\
-0.09 \\
-0.35 \\
-0.42\end{array}$ & $\begin{array}{l}-0.27 \\
-0.13 \\
-0.47 \\
-0.50\end{array}$ \\
\hline
\end{tabular}

cumulative relationship between byssinosis prevalence and length of service, ignoring secular changes in the factory population. The nature of the association between length of service and the risk of developing byssinosis cannot be deduced from it. In this factory the risk is not confined to those with several years of exposure to hemp dust. Out of the 17 workers who had been employed for less than one year three had developed byssinosis; one was a woman in the hackling section who was classified as a grade 2 byssinotic. The relative importance of age and length of service in the development of the disease also remains uncertain. However, among the 23 workers who had been employed for one year or less, the four byssinotics had a mean age of 35 years compared with a mean of 25 years for workers without byssinosis, suggesting that the older workers may be more susceptible.

By comparing the byssinosis prevalence in the working sections exposed to hemp dust, adjusted for length of service, only two differences were found to be statistically significant. The adjusted prevalence for wet spinners was zero compared with an adjusted prevalence of $66.5 \%$ for the strippers and grinders and $63.4 \%$ for the hacklers. Several of the other differences between sections were quite large, but the smallness of the groups may have prevented them from being statistically significant.

Chronic bronchitis was diagnosed in $15.1 \%$ of the workers in the spinning department but was not found in any of the controls. Out of the 16 workers with chronic bronchitis I4 also suffered from byssinosis. The association between byssinosis and chronic bronchitis in workers in the spinning department was statistically significant, but there appeared to be no association between the severity of byssinosis and the presence of chronic bronchitis.

The F.E.V ${ }_{0.75}$ and F.V.C. measured at the beginning of the shift were used as indicators of the long-term effects of hemp dust on the ventilatory function of the lung. After adjustment for age, sitting height, and sex, examination of the mean F.E.V ${ }_{0.75}$ and F.V.C. in the working sections failed to show any meaningful association between ventilatory capacity and the present occupation of the workers, and there were no statistically significant differences between sections in the ageadjusted F.E.V $\cdot_{0.75} /$ F.V.C. ratio. That the strippers and grinders had the highest mean adjusted F.E.V $\cdot 0.75$ and F.V.C. of all the occupational groups could possibly be explained by the fact that they are selected from the strongest available workers, as their work is physically very strenuous. In spite of exposure to high peak concentrations of dust, no reduction in ventilatory capacity may have occurred owing to their exposure being intermittent and their length of service very short. When the three respiratory disease groups, byssinotics with chronic bronchitis, byssinotics without chronic bronchitis, and workers with neither disease, were compared the mean age-adjusted F.E.V ${ }_{0.75} /$ F.V.C. ratio decreased steadily with each additional respiratory disease, but the only statistically significant difference was between the byssinotics with chronic bronchitis and the workers with neither disease.

The changes in F.E.V $\cdot_{0.75}$ and F.V.C. during the shift were used to assess the acute effects of hemp dust on the ventilatory capacity of the lung. With the exception of the wet spinners, the F.E.V $\cdot_{0.75}$ and F.V.C. showed a mean decrease during the shift in all working sections. The decrease tended to be greater in the sections exposed to higher dust concentrations. The mean decrease of both F.E.V $\cdot_{0.75}$ and F.V.C. was greater in strippers and grinders, carders, hacklers, drawers, and spinners than in the controls. All the working sections had statistically greater mean decreases in both tests than the wet spinners whose dust exposure is comparatively low.

In workers exposed to high levels of hemp dust, a comparison of three respiratory disease groups, 
atter weighting to allow for differences in exposure, showed that the byssinotics with chronic bronchitis had a significantly greater mean decrease in F.E.V.0.75 during the shift than the byssinotics without chronic bronchitis and the workers with neither disease. There were no statistically significant differences between the three groups with respect to the change in F.V.C. during the shift.

When the workers were classified by grade of byssinosis the mean change during the shift in F.E.V.0.75 and F.V.C. for all sections combined showed a decrease that became progressively greater as the severity of the disease increased.

From the above results it is clear that exposure to the dust of Cannabis sativa hemp causes temporary impairment of ventilatory function, varying in severity according to the level of dust concentration and the presence of respiratory disease. The reduced F.E.V.0.75 $/$ F.V.C. ratio of workers with byssinosis provides some evidence of a long-term effect of exposure to hemp dust. The lack of association between ventilatory capacity and present occupation may be due to a rather high fluctuation of workers among various sections in previous years, when the organization of work in the factory was different, and to the relatively short duration of service in all exposed groups except the wet spinners, whose level of dust exposure is low.

During our survey all three members of the team taking dust samples, and spending voluntarily 8 to Io hours on end daily in the dusty parts of the factory, developed typical symptoms of byssinosis, with significant reductions in ventilatory capacity decreasing in the course of the week. Two of them also had muscle pains similar to those which develop during influenza. The reaction to hemp dust exposure was undoubtedly more violent than that experienced in connexion with cotton dust exposure of a similar level.

We wish to thank Professor R. S. F. Schilling for help and advice in preparing this paper, Mr. I. Balog of the 'Andrija Stampar' School of Public Health for help with the dust sampling, and Miss Sheila Farrow for computing assistance.

\section{REFERENCES}

Barbero Carnicero, A., and Flores Marco, R. (1944). Enfermedad del cañamo. Rev. clin. esp., 13, 395-399.

Bouhuys, A., Barbero Carnicero, A., Lindell, S. E., Roach, S. A., and Schilling, R. S. F. (1967). Byssinosis in hemp workers. Arch. environm. Hlth, 14, 533-544.

Gilson, J. C., Stott, H., Hopwood, B. E. C., Roach, S. A., McKerrow, C. B., and Schilling, R. S. F. (1962). Byssinosis: the acute effect on ventilatory capacity of dusts in cotton ginneries, cotton, sisal and jute mills. Brit. F. industr. Med., 19, 9-18.

Jiménez Díaz, C., and Lahoz, C. (1944). La cannabosis (enfermedad de los trabajadores del cáñamo). Rev. clin. esp., 14, 366-376.

Lammers, B., Schilling, R. S. F., and Walford, Joan. (1964). A study of byssinosis, chronic respiratory symptoms, and ventilatory capacity in English and Dutch cotton workers, with special reference to atmospheric pollution. Brit. F. industr. Med., 21, 124-134.

McKerrow, C. B., Gilson, J. C., Schilling, R. S. F., and Skidmore, J. W. (I965). Respiratory function and symptoms in rope makers. Ibid., 22, 204-209.

Miller, W. F., Johnson, R. L., Jr., and Wu, N. (1959). Relationships between fast vital capacity and various timed expiratory capacities. F. appl. Physiol., 14, 157-163.

Munt, D. F., Gauvain, Suzette, Walford, Joan, and Schilling, R. S. F. (1965). Study of respiratory symptoms and ventilatory capacities among rope workers. Brit. $\mathcal{F}$. industr. Med., 22, 196-203.

Schilling, R. S. F., Vigliani, E. C., Lammers, B., Valić, F., and Gilson, J. C. (1964). A report on a conference on byssinosis. In Proc. XIV int. Congr. Occup. Hlth, Madrid, 1963. Vol. II, 137-145 [Exc. med. Int. Congr. Ser., No. 62].

Stott, H. (1958). Pulmonary disease amongst sisal workers. Brit. F. industr. Med., 15, 23-37.

Velvart, J., Stavrovská, O., and Hudáková, G. (1964). Uloha bronchiálnych spazmov pri konopárkom ochoreni (Role of bronchial spasms in hemp processing). Pracov. Lék., 16, 397-400.

Walford, Joan, Lammers, B., Schilling, R. S. F., van den Hoven van Genderen, D., and van der Veen, Y. G. (1966). Diurnal variation in ventilatory capacity. An epidemiological study of cotton and other factory workers employed on shift work. Brit. F. industr. Med., 23, I42-I 48.

Werner, G. C. H. (1955). De la bronchiolite oedémateuse allergique. Essai statistique sur l'asthme des poussières textiles végétales. Arch. Mal. prof., 16, 27-45. 